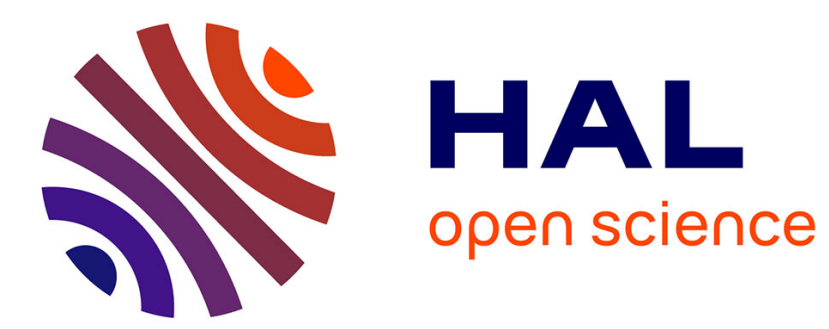

\title{
The locus of power in UK universities
}

Laurie Lomas

\section{To cite this version:}

Laurie Lomas. The locus of power in UK universities. Active Learning in Higher Education, 2006, 7 (3), pp.243-255. 10.1177/1469787406071214 . hal-00571954

\section{HAL Id: hal-00571954 https://hal.science/hal-00571954}

Submitted on 1 Mar 2011

HAL is a multi-disciplinary open access archive for the deposit and dissemination of scientific research documents, whether they are published or not. The documents may come from teaching and research institutions in France or abroad, or from public or private research centers.
L'archive ouverte pluridisciplinaire HAL, est destinée au dépôt et à la diffusion de documents scientifiques de niveau recherche, publiés ou non, émanant des établissements d'enseignement et de recherche français ou étrangers, des laboratoires publics ou privés. 


\section{The locus of power in UK universities}

\section{Its impact on educational development}

centres

\section{LAU R IE L O MAS King's Institute of Learning and Teaching, King's College London, UK}

ABSTRACT This article identifies the increasing demands on United Kingdom universities brought about by the expanded government agenda and the entry of higher numbers of more diverse students. It analyses the changes in organizational structures and cultures and identifies a centralizing tendency in terms of power to meet these demands. There is a focus on directors of educational development centres to explore how they have responded to the challenge of implementing their universities' teaching and learning strategies in a changing and uncertain environment. There is an examination of how they identify the locus of power, their priorities, the leadership skills they employ and the coalitions they build.

KEYWORDS: accountability, autonomy, coalitions, leadership, organizational culture, organizational structure

\section{Introduction}

Since the latter part of the twentieth century, there has been a period of significant change in the higher education sector in the United Kingdom (Morley, 2003). Henkel (2000) notes that universities have necessarily adapted to the government's drive for greater public accountability, efficiency and the measurement of performance. They also have to teach increased numbers of more diverse students (Hativa and Goodyear, 2002) when the level of resource per student is falling (Evans and Nation, 2000; Duke, 2002). The widening government agenda has led to lecturers working with students from diverse backgrounds, paying more attention to teaching, learning and assessment, developing students' generic and subject skills so that they have greater employability whilst continuing to develop in their students a deep understanding of complex subject matter (Knight and Yorke, 2003). 
Responses to the external pressure from government agencies such as the Higher Education Funding Council for England, the Quality Assurance Agency and the Higher Education Academy have been manifested in changes in universities' organizational culture and structure. These changes have led, in many cases, to a shift in the locus of power, which can affect decisionmaking related to learning and teaching. Morley (2003) argues that power is based on the creation and maintenance of particular norms in the relationships between individuals and groups in a university. It is easy to identify the locus of power when it is exercised overtly but Morley warns that this is not always so, as sometimes power is exercised subtly and the locus is not easily distinguishable. Therefore care needs to be taken when analysing the locus of power. Organizational structure and organizational culture will be used as a framework for this analysis. Duke (2002) notes that these elements of the framework are linked, because a university's organizational structure and management are key factors in determining its organizational culture.

Changes in the locus of power have had a significant effect on the development, implementation, monitoring and review of universities' learning and teaching strategies. The locus of power in their institutions influences and shapes strategy. Educational developers need to watch carefully to find out where the power lies in their university in order to know with whom to form strategic alliances and thereby 'tap in' to this power (Land, 2004).

\section{Organizational structure}

The recent widening of the economic and social roles expected of universities by government has meant that there is increasing complexity in terms of their structure (Shattock, 2003). Land (2004) notes that universities are large multifaceted structures with planning cycles that are similar to major commercial and industrial companies.

Universities' organizational structures are affected by numerous factors such as age of the institution, the disciplinary mix, tradition and size. Collegial universities such as Oxford and Cambridge and civic universities have very traditional structures, and McNay (2002) argues that, because they are departmentally based, there is less central power than in many post-1992 universities. Collegial values still flourish and some of the institutions remain loosely coupled, high consensus organizations (Scott, 2003). Becher and Trowler (2001) see academic departments as the essential building block and Shattock (2003) identifies the appropriate acculturation of newcomers to the department by existing staff who make the general values and the norms of behaviour abundantly clear. In terms of teaching and learning initiatives, the power in these collegial universities resides in 
the departments. Some departments are baronial and fiercely protective of their own staff, students and courses and compete aggressively with other departmental heads for scarce resources (Land, 2004).

D'Andrea and Gosling (2005) identify a recent trend for senior management grouping departments together, partly because of administrative convenience but also because of the economies of scale that accrue from having larger units. Such changes to organizational structure reduce the power of the departments by subverting their individual identities.

Where there is a focus on faculties (a collection of a number of similar academic departments) rather than on departments, real power is more likely to reside with the deans who lead the faculties. Shattock (2003) argues that medical and dental schools within a university often have a significant degree of autonomy with many decision-making powers devolved to them. Medical and dental schools have to be able to respond to the needs of the hospital trusts and the United Kingdom government's agenda for the National Health Service. Increased autonomy allows the deans to respond appropriately.

A relatively simplified approach to structure has been adopted in this article but Barnett (2000) talks of 'supercomplexity' with universities and their staff having to struggle to keep up with changes and the need for flexible and adaptable structures. There are a variety of organizational structures that have been chosen to cope with increasing government demands and the 'supercomplexity' of higher education.

\section{Organizational culture}

Organizational culture involves traditional beliefs, values and behaviour as well as an identifiable difference between those on the inside and those on the outside of the organization or a particular part of it (Barnett, 1990). Although culture is used regularly to help understand how organizations act and react, it should be pointed out that culture is not universally accepted as a helpful analytical tool. Kogan (1999), for example, describes the concept of organizational culture in higher education as merely 'intellectual polyfiller' which is used in an attempt to explain the inexplicable; it should be noted that this is a minority view.

Dopson and McNay's (1996) work on discerning a university's dominant culture provides a useful framework for looking at the different ways in which policies and practices, such as those related to teaching and learning, are developed and implemented in a university. They identify four main cultures and their principal features, processes and key 'players', but any organizational culture tends not to be pure but rather a blend of all four with, perhaps, one or two of them dominating (see Table 1). 
Table I The four major organizational cultures in universities (Dopson and McNay, 1996)

\begin{tabular}{llll}
\hline Collegial & Bureaucratic & Entrepreneurial & Corporate \\
\hline Cult of individual & Rules and & Awareness of & Directorate with \\
& regulations & the market & power \\
Management by & Management by & Management by & Management by \\
consensus & committees & marketing & meetings \\
Person culture & Role culture & Task culture & Power culture \\
\hline
\end{tabular}

Modern post-1992 universities, when they were previously polytechnics, were centrally managed, with their degrees being conferred through the Council for National Academic Awards (CNAA). They were familiar with a measure of central control through the CNAA's formal quality assurance procedures, and this became very much part of their organizational culture on becoming universities. Morley (2003) believes there is much less of a collegial culture than is the case in the traditional pre-1992 universities.

McNay (1995: 105) has identified a change in dominant culture in the higher education sector 'from the collegial academy to corporate enterprise', where, even at the University of Oxford, '. . . the preconditions for good collegial governance have been undermined' (Tapper and Palfreyman, 2000: 143). Sawbridge (1996) argues that employer-led management initiatives such as appraisal, performance-related pay and centralized staff development have led to greater standardization which, in turn, has threatened the collegial ideal. Generally, quality assurance systems have shifted the balance of power to the centre (Kogan and Hanney, 2000) but, with the great diversity of mission statements in UK universities, the extent of this shift in dominant culture varies greatly both between and within particular institutions.

The analysis of organizational culture suggests that more power is located at the centre of universities as entrepreneurial and corporate cultures develop as a response to changes in the higher education market place.

\section{The centralizing tendency}

It is possible to identify different types of university (Duke, 1992), although distinctions are becoming blurred due to, for example, increasing 'supercomplexity'. Overall the literature highlights a centralizing tendency with the growth of a managerialist perspective, particularly in post-1992 universities (see Figure 1). The figure shows movement of control from departments to the centre and communication between groups becoming 


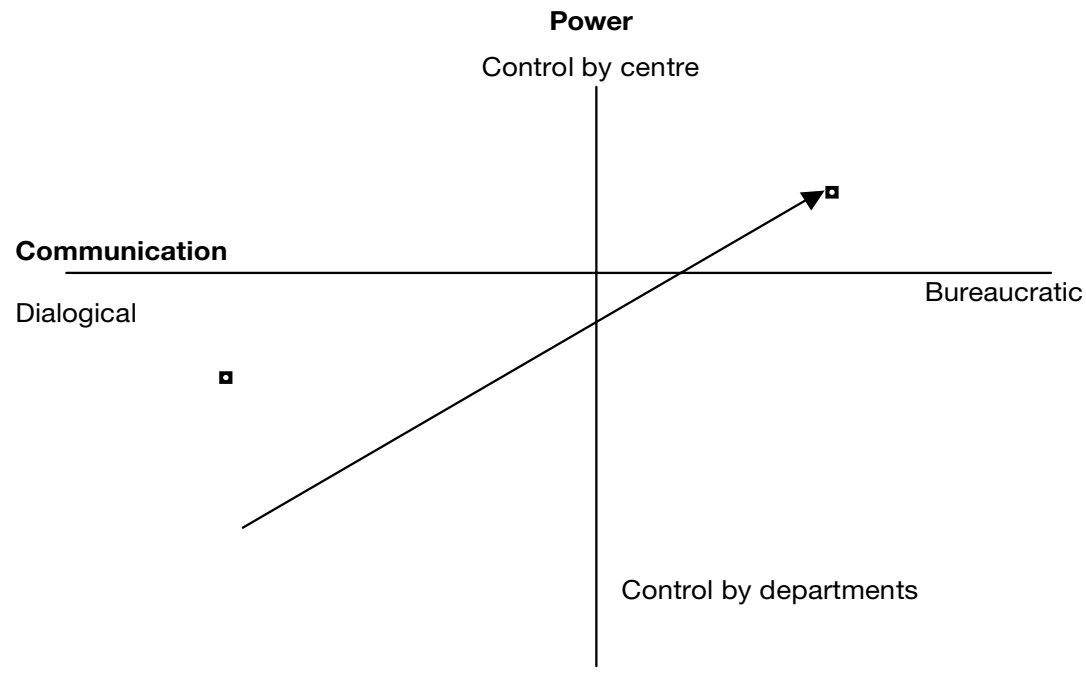

Figure 1 The centralizing tendency in universities

Based on Brown, R. (2004)

more formalized. Strongly departmentally based Oxbridge and civic universities have less central power than the post-1992 modern universities. Where there are medical and dental schools (faculties), the real power can lie with the deans as they often have a significant amount of autonomy with many decision-making powers devolved to them.

If educational development unit staff are able to identify the locus of power, they then know their target and the battle ground.

\section{Teaching and learning}

Termed the 'commodification of learning', Taylor et al. (2002) argue that the learner is now seen as a customer and a consumer of learning within a market place. There is a tighter coupling between general performance by universities and funding (Johnson, 2002), and Barnett (2004) refers to the notion of performativity with its insistence on demonstrable outcomes.

In terms of curriculum, from the 1990s there has been a centralizing tendency with the emphasis on learning outcomes, modulization, credit accumulation and transferable skills (Land, 2004). All such developments can be seen as examples of the commodification of learning (Hussey and Smith, 2002). Barnett (2004) identifies a discernible move away from prepositional discipline-based knowledge to more generic experiential learning and problem-based learning and transferable skills. Power over the curriculum is gravitating towards the centre of universities and away from the departments with the introduction of subject benchmarks, the National 
Qualifications Framework and programme specifications (Morley, 2003). Educational development units, under the watchful eyes of members of the senior management team, have been responsible for providing training on these central government curriculum initiatives and academic standards units for ensuring that the departments' curriculum design and developments take account of them. This centralizing tendency has been particularly noticeable in post-1992 modern universities.

Education development units have the task of developing and implementing the university's teaching and learning strategy but little is known about how they achieve this. Who are the power brokers with resources, for example? Who are the change champions at the top of the organization and with whom is it essential to build coalitions? What leadership skills are required to implement the teaching and learning strategy effectively? Literature has so far not detailed the views of directors of educational development units about where they consider power in their university is located and how, if at all, this power impacts upon them. The research described in this article seeks to address this gap in the literature by focusing on directors of educational development units to determine how they have responded to the shift in the locus of power and the leadership skills they utilize to implement their university's teaching and learning strategy.

\section{Methodology}

The research was undertaken in six relatively large English universities: three pre-1992 and three modern (post-1992). There were an equal number of respondents from pre- and post-1992 universities. The subject was considered to be of interest and consequently it was not difficult to find sufficient respondents. In-depth interviews were chosen as the research method because they allowed two-way communication, with the researcher being able to clarify any questions that were ambiguous. Also, interchange between the interviewer and the interviewees meant that probing, supplementary questions could be asked to follow up any interesting statements made by the interviewees (Cohen et al., 2000).

The research was undertaken by the author, who conducted the interviews from September to December 2005 using a semi-structured interview schedule. The main issues discussed related to the university's organizational culture and traditions and the development of the unit. The research also focused on the staff of the unit: how many there were; whether they held academic or academic-related contracts; whether they were permanent or temporary, full- or part-time; and what their academic qualifications and publications were. The unit's mission was explored: how was it funded; location in the university structure; and to whom the director reported. 
Directors were asked about their units' successes and disappointments and the probable reasons for these. An informal 'SWOT' analysis looked at the unit's strengths, weaknesses, opportunities and threats. Directors were also asked to identify what they regarded to be the main facilitating and inhibiting forces and the most helpful and effective coalition partners. The backgrounds of the directors were analysed, their gender, approximate age, their experience of higher education in general and educational development in particular and their academic discipline before moving into educational development. Data gained from the interviews was mostly qualitative but this was supplemented with quantitative data obtained from university prospectuses and educational development websites.

The identities of the six universities were protected by using pseudonyms to indicate their type and general location:

$\begin{array}{ll}\text { Regional Modern } & \text { Regional Traditional } \\ \text { Suburban Modern } & \text { Suburban Traditional } \\ \text { Urban Modern } & \text { Urban Traditional }\end{array}$

The qualitative data collected through the interviews was analysed by using the Constant Comparative Method (Strauss and Corbin, 1998), which involves ascribing meaning to a particular note in an interview. This is then compared with other interview notes and, when similarities of meaning are found, they are grouped and coded. If no similar meaning is found during a comparison, a new theme category is created. A number of categories were identified but the key ones relating to the locus of power in the six universities were:

- mission

- management of change problems

- where the battles have to be won.

\section{Results}

\section{The missions of the units}

Mission statements embody the values of the educational development units and are designed to ensure that everyone in the university knows what the units are aiming to achieve.

The six educational development units had broadly similar missions, with all of them expected to take the lead with national teaching and learning initiatives. Urban Modern University had a brief to develop and implement strategies to improve student learning across the university. The missions of Suburban Traditional and Regional Modern universities were to deliver the institution's learning and teaching strategy, whereas that of 
Urban Traditional University also included a role in promoting teaching and learning and encouraging pedagogic research. In part, this mission was to be achieved through the provision of nine teaching fellowships during a three-year period. The mission of Regional Traditional University was to enhance the policy of teaching and learning across the institution. The educational development unit at Suburban Modern University was charged with improving the quality of teaching and learning but, because it is a post-1992 modern university that lacked a research culture and received very limited research funding, it also had a major role in encouraging research skill development and a higher level of research outcomes.

\section{Management of change problems}

Three of the six directors raised major concerns about the effective management of change in their universities. They referred to the constraints caused by a lack of resources and appropriate staff (Suburban Modern University), the lack of recognition of the importance of excellence in teaching (Urban Traditional University) and inadequate resources to meet the external demands (Regional Modern University).

The director at Suburban Modern University thought that it was vital to have an advocate at senior management level to champion the cause of the unit and support claims for resources. It was important that the unit had a 'voice' because various departments and groups were competing for these limited resources and have their particular issues at the top of senior management's agenda. The director at Urban Traditional University said the unit suffered from not having a 'big hitter' in the senior management team speaking up for them.

The director at Suburban Modern University also argued that, as well as resources being a key issue, the academic credibility of the unit was an essential element if the teaching and learning strategy was to be implemented effectively. The director at Regional Traditional University was pleased to report that the unit was seen as academic as this gave her team credibility with the academic staff with whom they worked. She was keen that members of the team developed a research publication profile so that they fitted with the university's organizational culture.

At Suburban Traditional University, the director considered that the greatest challenge was to translate her unit's limited amount of authority into the maximum amount of control. She felt that this could be achieved by networking effectively and building political alliances with colleagues in various parts of the university noting that, ' . . . educational development is highly political and "smoozing" is a useful way of building coalitions to help achieve the unit's aims'.

At Urban Modern University the unit had great success in developing a 
Virtual Learning Environment (VLE). By encouraging and cajoling staff, the number of university modules on the VLE rapidly rose to over 50 per cent of the total. Academic Board noted this progress but, in order to increase the proportion of modules on the VLE further, it stated that at least some elements of all modules should be delivered by eLearning, and this led to a rate of about 80 per cent. However, some staff resented the Academic Board's directive and would have preferred a more consultative approach to eLearning.

The research was designed partly to identify the leadership skills required to implement the university's teaching and learning strategy effectively. The analysis of the management of change problems raised by directors highlights the political nature of the coalition building process and the importance of sensitive and empathetic leadership by the director of the educational development unit.

\section{Where battles have to be won}

At Urban Traditional University, the director believed that adequate resources were a priority and because of this battles had to be won at the centre initially and then in the faculties and departments. This was very problematic and fraught with difficulties. There were 'turf wars', with departments acting very territorially. The director of Suburban Traditional University agreed to add that the support of the senior management team at the centre was a prerequisite to persuading departments to review their teaching and learning approaches. At Suburban Modern University, it was noted that the institution was becoming more corporate and this probably explained why power was now more centralized. Consequently, the battles needed to be won at the centre to ensure that the education development unit was adequately resourced. Once that was achieved, the unit could turn to winning the hearts and minds of academic staff in the faculties and departments. An appropriate balance of support and pressure was needed here as pressure without support can easily lead to resistance and alienation whereas support without pressure can lead to drift and a loss of momentum (Fullan, 1991). The director at Regional Modern University did not have to 'battle' with the centre as the unit already had its backing. He thought the battles needed to be won in the faculties. However, although the senior management team and his unit put pressure on the faculties to change, very often the deans were not able to 'make things happen at grassroots level'. Similarly, the director at Regional Traditional University thought her unit was well resourced and so it could concentrate on winning over academic colleagues in faculties and departments. However, she said that there was a very great range of responses with some colleagues being most positive and others being openly hostile towards some learning and teaching initiatives. 
The director at Urban Modern University was a member of the senior management team. His line of communication and responsibility was directly to the Deputy Vice-Chancellor, and this meant he had very strong support from the centre of the organization. As a member of the senior management team he had regular contact with the five Deans of Faculty through whom he could influence the development of teaching and learning. The impact of the centre was further increased through the appointment of learning and teaching co-ordinators to each of the faculties. The centre had 'many tentacles' but the departments were the hardest to reach. The director considered that it was in the departments that the unit had to win the hearts and minds of the staff. He believed that,

Leadership in teaching and learning is my major role and I find that the faculty teaching and learning co-ordinators are invaluable in helping me get the messages into the departments.

To achieve greater acceptance of teaching and learning in departments, Regional Traditional and Regional Modern universities had also appointed faculty teaching and learning co-ordinators who were able to cascade down the teaching and learning initiatives to their constituent departments. Both universities had noted that departmental staff seemed more ready to accept suggestions from faculty teaching and learning co-ordinators than from members of the educational development unit. The director at Regional Modern University thought that this was because the teaching and learning co-ordinators were more closely associated with the departmental staff's academic 'tribes' (Becher and Trowler, 2001). He relied heavily on the faculty teaching and learning co-ordinators but they were only part-time for 0.2 in this role and consequently their impact was not as significant as he would like.

Again, the discussion of where the battles need to be won highlights the importance of leadership by the unit directors. The directors need staff within the faculties and departments to help champion teaching and learning enhancement and the co-ordinators play a very important role here. The amount of time they are allocated varies from 0.2 to 0.5 in the six units. The directors considered the higher figure to be the minimum requirement.

\section{Limitations of the research}

Although the in-depth interviews with the six directors yielded some interesting data, with such a small sample it is very difficult to draw conclusions which could be generalized to all universities. However, the units may be considered 'typical' and the results are illuminative. Further research involving a larger sample of directors would allow a more substantial investigation 
of the difference, if any, in the strategic and operational development of educational development units in modern post-1992 universities compared to their counterparts in pre-1992 universities.

Another limitation of the research was that it focused only on one of the groups of stakeholders involved with educational development. Future research will not only look at the perspectives of educational development unit directors but also those representatives of other stakeholder groups such as members of the units and senior management teams, teaching and learning co-ordinators and departmental staff. The research will be extended to include a larger sample of unit directors and conduct in-depth interviews with a similar number of representatives from the other stakeholder groups. By increasing the number of stakeholder groups involved, data triangulation would be achieved and consequently the validity of the research enhanced (Massey and Walford, 1999).

The research was restricted to English universities. Future work will include education development units in Scotland, Wales and continental Europe, thereby providing an international comparative dimension.

\section{Conclusion}

The literature clearly indicates a tendency for power to move to the centre of universities as senior managers attempt to meet the challenges of a greater number and diversity of students and the ever-expanding expectations of government, employers, students and their parents. The norms that have been established in the power relationships between individuals and groups show a centralizing tendency, particularly in post-1992 universities. Recent centrally directed curriculum initiatives such as the National Qualifications Framework, subject benchmarks and programme specifications and teaching and learning developments involving emphasis on learning outcomes and transferable skills, have expanded the role of educational development units.

The research reveals major concern amongst directors about the level of funding. Funding is thought by the majority to be inadequate to allow units to implement effectively the numerous teaching and learning initiatives that government agencies require. Where funding is an issue, units see the centre of the organization as its initial target. Educational developmental units that receive relatively generous funding do not need to 'battle' with the centre. They can target the academic staff either at faculty or departmental level, depending on the location of power in their particular university.

Wherever the battle is being fought, the skill of the director in deploying subtlety and perseverance is essential in building coalitions with colleagues in departments, faculties and at the centre. In a university there 
are organizational territories with barriers. The director's leadership skills of diplomacy, sensitivity and empathy help the unit penetrate these barriers and work with academic staff to implement the university's teaching and learning strategy. The appointment of faculty teaching and learning coordinators can also greatly assist the director with this.

Two directors referred to the importance of their unit having academic credibility. The organizational culture of the unit will need to be similar to that of the faculties and/or departments. If academic kudos and credibility are acquired through having a good record of presenting papers at conferences and publishing articles in refereed journals, then the staff of the unit will need to be successful in these areas.

An educational development unit also needs a 'champion' in the senior management team to advance its causes by speaking up to ensure it receives adequate resources and that its issues and concerns are prominent on the senior management team's agenda.

The role of a university's educational development unit is a challenging one but awareness of the locus of power, the value of particular leadership skills and building coalitions can greatly assist directors to implement effectively their university's teaching and learning strategy.

\section{References}

BARNETT, R. (1990) The Idea of Higher Education. Buckingham: SRHE/Open University Press.

BARnett, R. (2000) Realizing the University in an Age of Supercomplexity. Buckingham: SRHE/Open University Press.

BARnetT, R. (2004) 'Forword', in B. MacFarlane, Teaching with Integrity. London: RoutledgeFalmer.

Becher, t. \& Trowler, P. (2001) Academic Tribes and Territories. Buckingham: Open University Press/SRHE.

BROWN, R. (2004) Quality Assurance in Higher Education: The UK Experience since 1992. London: RoutledgeFalmer.

COHEN, L., MANION, L. \& MORRISON, K. (2000) Research Methods in Education (5th edn). London: Routledge.

D'ANDREA, v. \& GOSLING, D. (2005) Improving Teaching and Learning in Higher Education. Maidenhead: SRHE/Open University Press.

DOPSON, S. \& MCNAY, I. (1996) 'Organisational Culture', in D. Warner \&

D. Palfreyman (eds) Higher Education Management, pp. 16-32. Buckingham:

Open University Press.

DUKE, C. (1992) The Learning University: Towards a New Paradigm. Buckingham:

SRHE/Open University Press.

DUKE, C. (2002) Managing the Learning University. Buckingham: SRHE/Open University Press.

EVAns, T. \& NATION, D. (2000) Changing University Teaching - Reflections on Creating Educational Technologies. London: Kogan Page.

fullan, M. (1991) The New Meaning of Educational Change (2nd edn). London: Cassell. 
hativa, N. \& GOOdyear, P. (2002) Teacher Thinking, Beliefs and Knowledge in Higher Education. London: Kluwer Academic Publishers.

Henkel, M. (2000) Academic Identities and Policy Change in Higher Education. London: Jessica Kingsley Publishers.

hussey, T. \& Smith, P. (2002) 'The Trouble with Learning Outcomes', Active Learning in Higher Education 3(3): 220-33.

Johnson, R. (2002) 'Resources in the Management of Change in Higher Education', in P. Trowler (ed.) Higher Education Policy and Institutional Change: Intentions and Outcomes in Turbulent Environments, pp. 79-107. Buckingham: SRHE/Open University Press.

KNIGHT, P. \& YORKE, M. (2003) Assessment, Learning and Employability. Maidenhead: SRHE/Open University Press.

KOGAN, M. (1999) 'The Culture of Academe', review of P. Maassen, Governmental Steering and the Academic Culture, Minerva 37: 63-74.

KOGAn, M. \& HANney, S. (2000) Reforming Higher Education. London: Jessica Kingsley. LAND, R. (2004) Educational Development: Discourse, Identity and Practice. Maidenhead: SRHE/Open University Press.

MCNAY, I. (1995) 'From the Collegial Academy to Corporate Enterprise: The Changing Cultures of Universities', in T. Schuller (ed.) The Changing University, pp. 105-15. Buckingham: Open University Press.

MCNAy, I. (2002) 'Governance and Decision-making in Smaller Universities', Higher Education Quarterly 56(3): 303-15.

MASSEY, A. \& WALFORD, G., EDS (1999) Explorations in Methodology, Studies in Educational Ethnography. Stamford: JAI Press.

MORLey, L. (2003) Quality and Power in Higher Education. SRHE/Open University Press: Maidenhead.

SAWBridge, M. (1996) 'The Politics and Organisational Complexity of Staff Development for Academics: A Discussion Paper’, Occasional Green Paper, No. 14, Sheffield: UCofSDA/CVCP.

ScotT, P. (2003) 'Learning the Lessons', in D. Warner \& D. Palfreyman (eds) Managing Crisis, pp. 161-77. Maidenhead: McGraw Hill/Open University Press.

SHAtтock, M. (2003) Managing Successful Universities. Maidenhead: SRHE/Open University Press.

Strauss, A. \& CORBin, J. (1998) Basics of Qualitative Research: Techniques and Procedures for Developing Grounded Theory (2nd edn). London: SAGE.

tapper, t. \& palfreyman, D. (2000) Oxford and the Decline of the Collegiate Tradition. London: Woburn Press.

TAYlor, R., BARR, J. \& SteEle, T. (2002) For a Radical Higher Education: After Postmodernism. Buckingham: SRHE/Open University Press.

\section{Biographical note}

LAURIE LOMAS is Assistant Director (Programmes) at King's Institute of Learning and Teaching, King's College London. He is responsible for academic practice programmes for staff at the College. His research interests and publications focus on higher education management.

Address: King's Institute of Learning and Teaching, King's College London, James Clerk Maxwell Building, 57 Waterloo Road, London SE1 8WA, UK.

[email: laurie.lomas@kcl.ac.uk] 